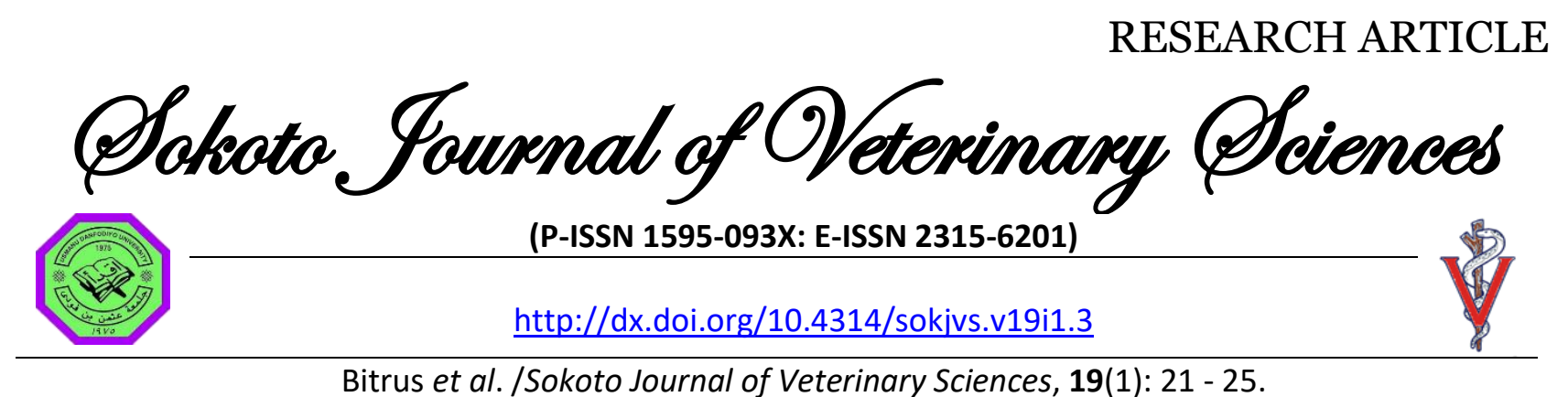

\title{
Occurrence of haemoparasites in cattle slaughtered at Jalingo abattoir, north-eastern Nigeria
}

\author{
I Bitrus ${ }^{1 *}$, HI Musa², IU Hambali², M Konto ${ }^{3}$, I Shittu $^{1} \&$ PU Balami ${ }^{4}$ \\ 1. \\ Regional Laboratory for Animal Influenza and other Transboundary Animal Diseases, National Veterinary \\ Research Institute, Vom, Plateau State, Nigeria \\ 2. \\ Department of Veterinary Public Health and Preventative Medicine, Faculty of Veterinary Medicine \\ University of Maiduguri, Borno State, Nigeria \\ 3. \\ Department of Veterinary Parasitology and Entomology, Faculty of Veterinary Medicine, University of \\ Maiduguri, Maiduguri Borno State, Nigeria \\ 4. National Veterinary Research Institute, Jalingo Zonal office, Taraba State, Nigeria
}

*Correspondence: Tel.: +2347039085893; E-mail: usfilmalgwi@yahoo.com

\begin{abstract}
Copyright: (C) 2021
Bitrus et al. This is an

open-access article

published under the

terms of the Creative

Commons Attribution

License which permits

unrestricted use,

distribution, and

reproduction in any

medium, provided the

original author and source are credited.
\end{abstract}

Publication History:

Received: 29-07-2020

Revised: 24-11-2020

Accepted: 25-11-2020

\section{Abstract}

Livestock plays a significant role in the economy of a nation but its productivity can be hampered by numerous haemoparasites thereby leading to economic losses to the livestock industry. The prevalence of haemoparasite in cattle slaughtered at Jalingo abattoir was investigated. A total of four hundred blood samples were collected at the point of slaughter, processed, and screened for haemoparasites by examining Giemsa-stained thin blood smears. An overall prevalence of $12.25 \%$ was recorded. Four haemoparasites of cattle with prevalence rates of $5.0 \%, 6.75 \%, 0.25 \%$, and $0.25 \%$ for Anaplasma, Babesia, Microfilaria and Trypanosoma respectively were observed. The prevalence of haemoparasite in relation to sex, revealed higher infection in females $(13.75 \%)$ than in males $(10.0 \%)$ which were not found statistically different $(P>0.05)$. All breeds encountered during the study were infected with haemoparasites with the highest prevalence of $13.91 \%$ recorded in White Fulani, Red Bororo (10.94\%), and Sokoto Gudali (10.00\%), while Adamawa Gudali had the least prevalence of $0.5 \%$. There was no statistically significant difference in the prevalence of haemoparasite in relation to breeds $(P>0.05)$. High prevalence was observed in the young $(14.29 \%)$ more than the adult $(11.59 \%)$ and older $(12.14 \%)$. The current study has revealed the haemoparasites status in cattle slaughtered at Jalingo abattoir. Therefore, there is a need for effective preventive and control policy of these haemoparasites to enhance livestock productivity.

Keywords: Abattoir, cattle, haemoparasite, prevalence, slaughter

\section{Introduction}

Nigeria has about $10-15$ million cattle, which accounts for one-third of agricultural gross domestic product (GDP), providing income, employment generation, food, draught power, hide and skin, farm 
manure, transport, and major source of government revenue (Oluwafemi et al., 2001; NLS, 2009). Cattle in Nigeria may be infected with a wide range of vector-borne haemoparasites transmitted by ticks and tsetse flies (Soulsby, 1982; FAO, 1984). The most economically important genera are Trypanosoma, Babesia, Anaplasma, Ehrlichia, and Theileria (Kamani et al., 2010). Their negative impact on health, productivity, reproduction, and performance of affected animals accounts for economic losses to livestock producers in the tropics and subtropics (Soulsby, 1982; FAO, 1984; Abdullah et al., 2019). Parasitic diseases have debilitating effects on human and animal health worldwide, particularly in developing countries (Ellis et al., 2003). The direct losses caused by haemoparasites are connected to acute illness and death, premature slaughter and rejection of some body part at meat inspection, while indirect losses comprise of drop in production potentials, such as decreased growth rate, anemia, jaundice, infertility, anorexia, loss of weight in young growing animals and late maturity of reproducing and slaughter stock (Hansen \& Perry, 1994; Ademola \& Onyiche, 2013; Opara et al., 2016). In several studies carried out on haemoparasites of cattle in Nigeria Agu et al. (1990) and Enwezor et al. (2009) reported a prevalence of $9.4 \%$ and $13.5 \%$ both in Kaduna north-western part of Nigeria. In a similar study conducted in north-central Nigeria, Kamani et al. (2010) reported a prevalence rate of $25.7 \%$. In cattle slaughtered from Gboko, Benue state, Zawua et al. (2015) reported a prevalence of $28.9 \%$ while Adua \& Idahor (2017) in Lafiya reported a prevalence of $20.1 \%$. In another study conducted in Ebonyi and Calabar states south-east and south-south parts of Nigeria, Agu \& Amadi (2001) and Enogiomwan et al. (2019) reported prevalence of $3.9 \%$ and $7.78 \%$ respectively. $6.67 \%$ prevalence of haemoparasite in Ibadan, Oyo state, south-western Nigeria was also reported by Okorafor \& Nzeako (2014). Although several studies have been carried out on haemoparasites of cattle in parts of Nigeria, there is a scarcity of information regarding haemoparasitic diseases in Jalingo. Hence, the present study was undertaken to determine the occurrence of haemoparasites of cattle slaughtered at the Jalingo abattoir, north-eastern Nigeria.

\section{Materials and Methods}

Study area

The study was conducted in Jalingo, the capital city of Taraba State, north-eastern Nigeria. Jalingo is located between latitudes $8947^{\prime}$ to $9001^{\prime} \mathrm{N}$ and longitudes $11^{\circ} 09^{\prime}$ to $11^{\circ} 30^{\prime} \mathrm{E}$. To the north it is bounded by Lau Local Government Area and to the east by Yorro Local Government Area, to the south and west by Ardo Kola Local Government Area. It has an overall land area of about $195 \mathrm{~km}^{2}$ with a population of 140,318, people according to the 2006 population census, with a projected growth rate of 3\% (Shawulu et al., 2008). In 2014, the projected population was 165,774 (Oruonye, 2014). The study population consist of ruminant (cattle) slaughtered at the Jalingo abattoir. The abattoir has an average daily slaughter of 50-70 cattle (Orounye, 2015).

\section{Sample collection and processing}

Blood samples were aseptically collected randomly at the point of slaughter from 400 ruminants (cattle) of both sexes, different breeds, and age groups. About $5 \mathrm{ml}$ of blood sample from the jugular vein of each animal was collected into a well-labeled ethylene diamine tetra acetic acid (EDTA) tubes indicating sex, breed, and age of animal. Samples were then transported immediately in cooled box to the National Veterinary Research Institute (NVRI), Jalingo zonal office laboratory for analysis. In the laboratory, thin blood smears were prepared using the method described by Ademola \& Onyiche (2013). The smears were examined at $\times 100$ magnification (oil immersion) on an Olympus microscope for the presence and identification of blood parasites according to keys and descriptions as given by Soulsby (1982) and Taylor et al. (2016). Buffy coat concentration method was used for the detection of trypanosomes in the blood (Cheesewbrough, 2005).

\section{Statistical analysis}

Analysis using simple descriptive statistics for all parameters was conducted. Statistical package for social sciences (SPSS) was employed in analyzing the data in the study. A P-value of $<0.05$ was considered as significant.

\section{Results}

Haemoparasite distribution found in cattle slaughtered at Jalingo abattoir as presented in Table 1 indicate that out of the 400 cattle examined, 49 (12.25\%) were infected with different haemoparasites. Four haemoparasites of cattle were identified in this study; Anaplasma, Babesia, Microfilaria and Trypanosoma (Table 1).

Babesia spp was the most prevalent haemoparasite 27 (6.75\%), followed by Anaplasma spp 20 (5.0\%), while Microfilaria 1 (0.25\%) and Trypanosoma spp 1 $(0.25 \%)$ were the least prevalent recorded in the study (Table 1). Prevalence in relation to sex was 
higher in the female $33(13.75 \%)$ than in the male $16(10.0 \%)$ (Table 2), even though there was no significant association $\chi^{2}=0.262$, df $=1, p>0.05$. Tables 3 and 4 show the prevalence of haemoparasite in relation to breeds and age. All breeds of cattle examined were infected with haemoparasites. The highest prevalence was observed in White Fulani 13.91\% (37), followed by Red Bororo 10.94\% (7), Sokoto Gudali $10 \%$ (2), and Adamawa Gudali 6\% (6) in that order. Prevalence of haemoparasites in relation to breed had no significant association $\left(x^{2}=0.441, \mathrm{df}=3, \mathrm{p}>\right.$ $0.05)$. Young cattle above 1-5 years of age recorded the highest prevalence $14.29 \%$ (8) followed by age group $>10$ years (older) with prevalence of $12.14 \%$ (25), while lowest prevalence of $11.59 \%$ (16) was recorded in adult animals of age group $>6-10$ years (Adult).

\section{Discussion}

The study has revealed the prevalence of haemoparasite in cattle slaughtered in Jalingo abattoir, north-eastern Nigeria. Haemoparasite exerts negatively on the health, reproduction, and performance of affected animals and this can be of major constraints to livestock productivity.

The overall prevalence of $12.25 \%$ in this study is higher than earlier reports conducted on haemoparasites of cattle in several studies in Nigeria by Agu et al. (1990) in Kaduna; Agu \& Amadi (2001) in Ebonyi; Ademola \& Onyiche (2013) in Oyo; Okorafor \& Nzeako (2014) in Oyo; and Enogiomwan et al. (2019) in Calabar who reported prevalence of $9.4 \%, 3.9 \%, 6.67 \%, 5 \%$, and $7.78 \%$ respectively in cattle. However, Adua \& Idahor (2017), Kamani et al. (2010), Zawua et al. (2015) and Enwezor et al. (2009), reported higher prevalence of $20.1 \%, 25.7 \%$, $29.9 \%$ and $13.5 \%$ across some states in Nigeria. The $12.25 \%$ haemoparasitemia observed in this study suggest an incessant challenge by parasites and existence of carrier state of most animals (Okorafor \& Nzeako, 2014). The high prevalence of Babesia spp $6.75 \%$ and Anaplasma spp $5.0 \%$ recorded in this study could be attributed to the abundance of vector
Table 1: Prevalence (\%) of haemoparasites of cattle slaughtered in Jalingo abattoir

\begin{tabular}{lllcc}
\hline $\begin{array}{l}\text { Animal } \\
\text { examined }\end{array}$ & $\begin{array}{l}\text { No. } \\
\text { examined }\end{array}$ & Haemoparasite & $\begin{array}{l}\text { No. } \\
\text { positive }\end{array}$ & $\begin{array}{l}\text { Prevalence } \\
\%\end{array}$ \\
\hline \multirow{4}{*}{ Cattle } & \multirow{4}{*}{400} & Anaplasma spp. & 20 & 5.0 \\
& & Babesia spp. & 27 & 6.75 \\
& & Microfilaria spp. & 1 & 0.25 \\
& & Trypanosomes & 1 & 0.25 \\
Total & 400 & spp. & 49 & 12.25
\end{tabular}

Table 2: Sex related prevalence of haemoparasites of cattle slaughtered in Jalingo abattoir

\begin{tabular}{lccc}
\hline Sex of cattle & No. examined & No. positive & Prevalence (\%) \\
\hline Male & 160 & 16 & 10.0 \\
Female & 240 & 33 & 13.75 \\
Total & 400 & 49 & 12.25
\end{tabular}

Table 3: Breed related prevalence of haemoparasites of cattle slaughtered in Jalingo abattoir

\begin{tabular}{lccc}
\hline Breed & No. examined & No. positive & Prevalence \% \\
\hline Adamawa Gudali & 50 & 3 & 6 \\
Red Bororo & 64 & 7 & 10.94 \\
Sokoto Gudali & 20 & 2 & 10 \\
White Fulani & 266 & 37 & 13.91 \\
\hline Total & 400 & 49 & 12.25 \\
\hline$\left(\chi^{2}=0.441, d f=3, p>0.05\right)$ & &
\end{tabular}

Table 4: Age related prevalence of haemoparasites of cattle slaughtered

\begin{tabular}{lccc} 
in Jalingo abattoir & & & \\
\hline Age (Years) & No. examined & No. positive & Prevalence (\%) \\
\hline$>1-5$ (young) & 56 & 8 & 14.29 \\
$>5-10$ (Adult) & 138 & 16 & 11.59 \\
$>10$ (Old) & 206 & 25 & 12.14 \\
\hline Total & 400 & 49 & 12.25 \\
\hline
\end{tabular}

responsible for their transmission as both are tickborne parasite. The fact that Anaplasma can be transmitted by several means (biologically by ticks and mechanically by biting flies) could have been the cause of its high prevalence in this study (Abdullah et al., 2019). Similar studies by Paul et al. (2016) in Maiduguri and Enogiomwan et al. (2019) in Calabar recorded prevalence of $9.9 \%$ and $5.8 \%$ of Anaplasma in cattle. The observed $0.25 \%$ of Trypanosoma was lower than the $8.4 \%$ reported by Enwezor et al. (2009) in Kaduna state, $8.0 \%$ by Kamani et al. (2010) in north-central Nigeria and $3.81 \%$ by Okorafor \& Nzeako (2014) in Oyo state. The $0.25 \%$ prevalence of Microfilaria observed in the present study is lower than $1.4 \%$ reported by Kamani et al. (2010). Disparities in prevalence of haemoparasites of cattle recorded in this study could be attributed to the 
difference in time of the study, breeds of animals sampled, differences in sample size, the diagnostic tool used, the management and nutritional status of animals sampled (Abdullah et al., 2019). Variations in geographical location (Velusamy et al., 2014) arbitrates the distribution of arthropod vectors of parasites (Agbede, 2013) and regular use of chemoprophylaxis and acricides by farmers could also account to local differences in the prevalence of haemoparasites (Ademola \& Onyiche, 2013). In female $13.75 \%$ (33) than in males $10.0 \%$ (16) confirms the reports of previous studies in Nigeria (Agu et al., 1990, Agu \& Amadi, 2001; Enwezor et al., 2009; Kamani et al., 2010 and Okorafor \& Nzeako, 2014) who attribute the accumulation of parasites by the females due to the extended breeding for economic reasons such as calving and milk production. The susceptibility of cows might also be attributed to reduced immunity as a result of stress due to pregnancy and lactation (Okorafor \& Nzeako, 2014). The effects of age on prevalence of haemoparasites has been previously reported (Kamani et al., 2010; Alim et al., 2012; Ademola \& Onyiche, 2013; Okorafor \& Nzeako, 2014; Enogiomwan et al., 2019). Adult and older cattle in this study had lower prevalence of haemoparasitic infection compared to their younger counterparts, which confirms report of Ademola \& Onyiche (2013) who observed that prevalence of haemoparasites in ruminants decreased with increasing age. This is in contrast with report of Kamani et al. (2010) who reported a higher prevalence in older cattle and stated that this could be due to the fact that adults are readily more infected with haemoparasites than younger ones because of a longer period of exposure to the arthropod vectors. Restricted grazing of young animals which tend to reduce their chances of contacts with the vectors of their chances of contact with the vectors of these diseases may attributed to the lower prevalence as compared to the adult (Kamani et al., 2013). All the breeds examined in this study were infected with haemoparasite. This confirms the reports by Adua \& Idahor (2017) indicating that there was a possibility of no breed related resistance among the animal species studied. The highest prevalence was observed in the White Fulani 37 (37.91\%). This contradicts previous studies by Okorafor \& Nzeako (2014) and Adua \& Idahor (2017) who reported higher prevalence of haemoparasite in Sokoto Gudali and Red Bororo Breeds. Woolaston et al. (1991) reported that there could be genetic variations in resistance to parasites among ruminants. Therefore, a concerted effort to develop haemoparasite resistant species of cattle and goats is compulsory in order to boost animal production. Breed-related haemoparasite did not vary significantly $\left(x^{2}=0.441, d f=3, p>0.05\right)$ in the study.

The result of the present study indicates that haemoparasites are prevalent among cattle in the study area affecting $12.25 \%$ of the different cattle breeds in the area. Four haemoparasites; Anaplasma, Babesia, Microfilaria, and Trypanosoma were identified. Thus, routine Screening of haemoparasites carrier status is essential for prompt diagnosis and implementation of control measures to prevent economic losses in cattle.

\section{Conflicts of Interest}

The authors declare no conflict of interest.

\section{References}

Ademola IO \& Onyiche TE (2013). Haemoparasites and haematological parameters of slaughtered Ruminants and pigs at Bodija Abattoir, Ibadan, Nigeria. African Journal of Biomedical Research, 16(2): 101-5.

Adua MM \& Idahor KO (2017). Haematological evaluation of haemoparasites in cattle and goat slaughtered at Lafia abattior, Nigeria. Asian Journal of Biology, 4(1): 1-5.

Abdullah DA, Ali MS, Omer SG, Shola, Ola-Fadunsin SD, Ali FF \& Gimba FI (2019). Prevalence and climatic influence on hemoparasites of cattle and sheep in Mosul, Iraq. Journal of Advanced Veterinary and Animal Research, 6(4): 492-498.

Agbede RIS (2013). A guide to tropical veterinary Entomology. Mac chin multimedia designers, Zaria, Nigeria. Pp 108-109.

Agu WE, Kalejaiye JO \& Olatunde AO (1990). Prevalence of bovine trypanosomosis in some parts of Kaduna and Plateau states, Nigeria. Bulletin of Animal Health Production in Africa, 37(2): 161-166.

Agu WE \& Amadi IN (2001). Trypanosomosis of small ruminants (sheep and goats) and cattle in Abakaliki of Ebonyi State, Nigeria. Tropical Veterinary Parasitology, 19(2): 1-8.

Alim AM, Roy SDK, Sikder MMS, Hassan MM, Siddiki AZ \& Hossain MA (2012). Prevalence of hemoprotozoan diseases in cattle population of Chittagong division, Bangladesh. Pakistan Veterinary Journal, 32(2):221-224

Cheesbrough M. (2005) District laboratory practice in tropical countries. Cambridge: Cambridge University press. Pp 64-67. 
Ellis JT, Morrison DA \& Reichel MP (2003). Genomics and its impact on parasitology and the potential for development of new parasite control methods. DNA Cell Biology. 22(6), 395- 403.

Enogiomwan IE, Offiong EE \& Ukam UA (2019). Haemoparasitic infection and haematological indices of cattle slaughtered for sale in Calabar, Nigeria. International Journal of Veterinary Sciences and Animal Husbandry, 4(4): 07-11

Enwezor FNC, Umoh JU, Esievo KAN, Halid I, Zaria LT \& Anere JI (2009). Survey of bovine trypanosomosis in the Kachia Grazing Reserve, Kaduna State, Nigeria. Veterinary Parasitology, $159: 121-125$.

FAO (1984). Food and Agricultural Organization, Prevention of loss from tick-borne diseases and ticks in cattle imported by developing countries. In: Ticks and Tick-borne Disease Control. A practical field manual Food and Agricultural Organization, Rome, Italy. 11, 597-621.

Hanson J \& Perry B (1994). The Epidemiology, Diagnosis and Control of Helminth Parasites of Ruminants. A Handbook of the Food and Agricultural Organization of the United Nations, Rome, Italy. Pp 72-89.

Kamani JA, Sannusi OK, Eqwu GI, Dogo TJ, Tanko S, Kemza AE, Takarki DS \& Gbise (2010). Prevalence and significance of haemoparasitic infections of cattle in northCentral, Nigeria. Veterinary World, 3(10): 445-448.

NLS (2009). National Livestock Statistics. Estimated livestock numbers in Federal Republic of Nigeria (August and February 2006). National Livestock Statistics Newsletter, 26.4.3.

Okorafor UP \& Nzeako SO (2014). Prevalence of Haemoparasites of Cattle from Three Abattoirs in Ibadan Metropolis, Oyo State, Nigeria. International Journal of Scientific Research in Environmental Sciences, 2(7): 244-249.

Oluwafemi RA, llemobade AA \& Laseinde EAO (2001). Study of Tsetse fly and Bovine Trypanosomiasis in the Biological Control of Tsetse fly project area in L.G.A of Nasarawa State Nigeria. Master degree thesis report, 165-167.

Opara MN, Santali A, Mohammed BR \& Jegede OC (2016). Prevalence of haemoparasites of small ruminants in lafia nassarawa state: a guinea savannah zone of Nigeria. Journal Veterinary Advancement, 6(6):1251-7

Oruonye ED (2014). An assessment of the impact of road construction on land use pattern in urban centres in Nigeria: A case study of Jalingo LGA, Taraba State) Nigeria. Mediterranean Journal of Social Sciences, doi.10.5901/mjss.2014.v5n10p82.

Oruonye ED (2015). Challenges of Abattoir Waste Management in Jalingo Metropolis, Nigeria. International Journal of Research in Geography (IJRG), 1(2): 22-31

Paul BT, Bello AM, Ngari O, Mana HP, Gadzama MA \& Abba A (2016). Risk factors of haemoparasites and some haematological parameters of slaughtered trade cattle in Maiduguri, Nigeria. Journal of Veterinary Medicine and Animal Health, 8(8):83-88.

Shawulu, HM Adebayo AA \& Binbol NL (2008). Appraisal of the national poverty eradication programme (NAPEP) in Jalingo local government area, Taraba State Nigeria. Medwell Journals. The Social Sciences, 3(4): 291-296.

Soulsby ELB (1982). Helminths, Arthropods and Protozoan of Domestic Animals. seventh edition Bailliere Tindall, London, Pp 516538.

Taylor MA, Coop RL, Wall RL (2016). Veterinary Parasitology, fourth edition, Wiley Blackwell, Pp 239-256.

Velusamy N, Rani GI, Ponnudurai TJ, Harikrishnan T, Anna K, Arunachalam KS \& Anbarasi P (2014). Influence of Season, age and breed on prevalence of haemoprotozoan diseases in cattle of Tamil Nadu, India. Veterinary World. 7(8): 574-577.

Woolaston RR, Windon RG \& Gray GD (1991). Genetic variation in resistance to internal parasites in Armidale experimental flocks. In: Gray G.D. and Woolaston R.R. ed., Breeding for disease resistance in sheep. Melbourne, Australian Wool Corporation

Zawua TP, Amali O, Amuta EU \& Sar TT (2015). Haemoparasites of cattle slaughtered for sale within Gboko Metropolis of Benue State, Nigeria. Nigerian Journal of Parasitology, 36(1): 72-76. 